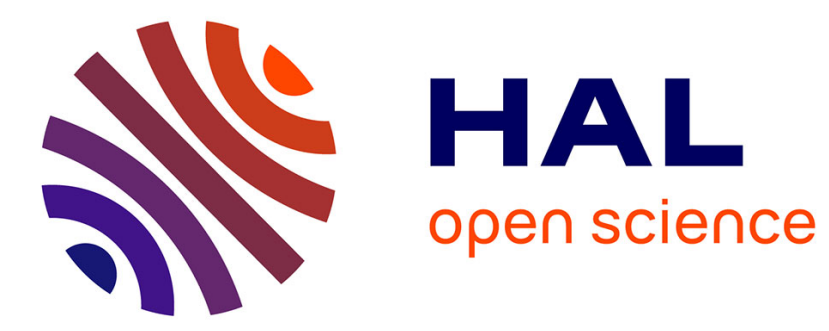

\title{
An algorithm for chemotherapy treatment of recurrent glioma patients after temozolomide failure in the general oncology setting
}

Athanassios P. Kyritsis, Victor A. Levin

\section{- To cite this version:}

Athanassios P. Kyritsis, Victor A. Levin. An algorithm for chemotherapy treatment of recurrent glioma patients after temozolomide failure in the general oncology setting. Cancer Chemotherapy and Pharmacology, 2011, 67 (5), pp.971-983. 10.1007/s00280-011-1617-9 . hal-00682813

\section{HAL Id: hal-00682813 \\ https://hal.science/hal-00682813}

Submitted on 27 Mar 2012

HAL is a multi-disciplinary open access archive for the deposit and dissemination of scientific research documents, whether they are published or not. The documents may come from teaching and research institutions in France or abroad, or from public or private research centers.
L'archive ouverte pluridisciplinaire HAL, est destinée au dépôt et à la diffusion de documents scientifiques de niveau recherche, publiés ou non, émanant des établissements d'enseignement et de recherche français ou étrangers, des laboratoires publics ou privés. 
An algorithm for chemotherapy treatment of recurrent glioma patients after temozolomide failure in the general oncology setting

\author{
Athanassios P. Kyritsis ${ }^{1,2}$, M.D., Victor A. Levin ${ }^{3,4}$, M.D.
}

${ }^{1}$ Neurosurgical Research Institute, University of Ioannina, Ioannina, 45110, Greece

${ }^{2}$ Department of Neurology, University of Ioannina School of Medicine, Ioannina, 45110,

Greece

${ }^{3}$ Professor Emeritus, Department of Neuro-Oncology, The University of Texas MD

Anderson Cancer Center, Houston, TX, 77030, USA

${ }^{4}$ Attending Physician at Kaiser Permanente, Redwood City, CA, 94063, USA

Keywords: glioma; glioblastoma; chemotherapy; temozolomide

Correspondence to:Athanassios P. Kyritsis, M.D., D.Sci.,

Dept. of Neurology,

University of Ioannina School of Medicine,

University Campus

Ioannina 45110, Greece

Phone: +30-26510-97514

Fax: +30-26510-97011

Email: thkyrits@uoi.gr 


\begin{abstract}
Purpose. The standard therapy for newly diagnosed malignant gliomas comprises surgery, radiotherapy, and commonly temozolomide chemotherapy. For recurrent or progressive disease after temozolomide failure there are no consensus and limited options for chemotherapy.
\end{abstract}

Methods. We reviewed the English literature for phase II trials of therapies for recurrent malignant glioma conducted between January 2000 and September 2010. The search was supplemented by a review of articles published prior of 2000 on chemotherapy regimens that had shown activity on recurrent gliomas.

Results. In order to guide practice in the general oncology setting an algorithm was constructed according to the activity of the reported chemotherapies at the time of writing. There are some molecular studies, performed on tumor tissue that may help to guide selection of chemotherapy. Methylated MGMT in tumor tissue correlates with increased sensitivity to alkylating agents such as fotemustine or other nitrosoureas. Depending on MGMT status and bone marrow reserve, treatment with fotemustine, bevacizumab, bevacizumab with irinotecan, or cis-retinoic acid (cRA), might be of value.

Conclusion. Unfortunately, progress in the development of new and more effective chemotherapy agents has been very limited and leaves the clinician treating high-grade glioma patients at relapse with few good options. The suggested algorithm is our objective evaluation of the currently existing knowledge. Hopefully, ongoing phase II and III trials will provide us the needed chemotherapy agents in the years to come. 


\section{Introduction}

High-grade gliomas (WHO grade 3 and 4 gliomas), and especially glioblastoma, are among the most difficult cancers to treat with short survival and poor response to chemotherapeutic drug intervention [1]. The reasons for the poor efficacy of these agents include the bloodbrain barrier which forms a pharmacological sanctuary, the expression of multidrug resistance proteins in glioma tumor cells and associated capillaries [2], the genetic, molecular, and metabolic heterogeneity of glioma tumor cells [3], resistance mechanism to commonly used alkylating agents, and, possibly, defects of both humoral and cellular immunity [4]. Tumor stem cells that exist within malignant gliomas, may provoke glioma development, perpetuation, and resistance to chemotherapy and radiation, accounting for the failure of conventional therapies and emergence of tumor recurrence [5]. In addition, radiation therapy, the primary treatment modality for gliomas, triggers several signal transduction pathways and toxic events to the tumor, such as direct DNA damage which can lead either to cell death or to mutations in the surviving tumor cells that might result in subsequent emergence of resistant clones and recurrence [6].

In general, postoperative adjuvant radiation therapy and chemotherapy with the second-generation monofunctional alkylating agent temozolomide (TMZ) became the standard care for newly diagnosed malignant gliomas soon after its introduction [7-9]. Unfortunately, high-grade gliomas usually recur despite treatment. In most cases, the radiographic determination of tumor growth is obvious, but sometimes radiation effect or outright radiation necrosis mimics tumor growth and requires different treatment. As a result, sometimes reoperation and/or biopsy are needed to confirm the diagnosis or to debulk tumor prior to chemotherapy. If surgery is not an option, specific imaging modalities, prior to initiation of secondary therapies, may help to establish the probability of tumor growth versus radiation effect [10-14]. 
For relapsed glioma patients that did not receive adjuvant TMZ chemotherapy, therapy with TMZ still remains a good choice $[15,16]$. Some authorities recommend rechallenge with alternative dosing TMZ for recurrent malignant gliomas even if patients had received previously standard TMZ chemotherapy [17-19]. Perry et al. using continuous dose-intense TMZ for recurrent or progressive gliomas on standard TMZ therapy reported benefit with 6month progression-free survival of $23.9 \%$ in patients with GBM and $35.7 \%$ in patients with anaplastic glioma [20]. In this review we evaluated all major phase II trials for recurrent gliomas, published after the emergence of TMZ and all active chemotherapies prior to the TMZ era. Our goal was to construct an algorithm for the general oncologist and not the specialist neuro-oncologist, how to treat an individual patient with recurrent glioma after TMZ failure, depending on the individual patient characteristics.

\section{Evaluation of phase II studies}

The criteria used to evaluate the various therapies include response rate which is associated with reduction in progression rate [21], histology which is a dominant factor in determining outcome [22], and progression-free survival (PFS) which is a more reliable end-point than overall survival since it reflects the true antitumor benefit of the chemotherapy [23] (Table 1). In addition, a six-month PFS is strongly associated with survival suggesting that it is a valid end point in recurrent glioma trials [24,25]. Objective response as an endpoint in phase II glioma trials may have limitations due to the frequent low response rates observed in recurrent glioma trials rendering extremely difficult to assess its predictive value to PFS and overall survival [26]. Furthermore, the radiologic assessment of response to treatment in patients with recurrent glioma is vulnerable to substantial inter-observer inconsistency [27]. However, if the treatment has efficacy and the objective response substantial, it may be linked 
to survival and could be a reliable predictor of a treatment benefit in recurrent glioma patients [28].

Typically, the rate of 6-month progression-free survival (PFS-6) is $21 \%$ for TMZ naïve patients with recurrent glioblastoma (GBM) after treatment with TMZ [15]. The PFS-6 in studies of patients with anaplastic glioma (AG) ranged from 37 to $41 \%$ [23]. After primary therapy with radiotherapy and TMZ followed by adjuvant TMZ, no standard salvage therapy exists for patients with high-grade glioma, although the FDA has approved recently an antiangiogenic therapy with bevacizumab for recurrent GBM because of promising response rates and increased median PFS [29].

\section{Molecular targeted therapies}

What defines this therapeutic approach varies among physician-scientists. On the one hand alkylating agents that "target" DNA could be called targeted therapy, although most consider targeted therapy to be therapy that is directed toward specific signaling pathways, whether cell surface receptors, signaling proteins in the cytosol, or enzymes important to transcription or DNA effects in the nucleus. Unfortunately, many of the new purported targeted therapies are, in fact, drugs that target anywhere from 3 to more than 5 other proteins and thus are far from being specific and targeted therapies. Common among many of the reversible tyrosine kinase inhibitors is unexpected systemic toxicity based on their promiscuous behaviour to receptor and intracellular kinases.

While many of the new targeted drugs have been studied alone, lack of definite activity in many cases has led to their use in combination with alkylating agents such as temozolomide or with other presumed targeting agents. Combination of molecularly targeted therapies, such as anti-angiogenesis through inhibition of the VEGFR pathway (eg, bevacizumab), EGF receptor tyrosine kinase inhibitors (gefitinib and erlotinib), PDGF 
receptor inhibitors (imatinib), mTOR inhibitors (temsirolimus and everolimus), and protein kinase C-beta and other angiogenesis pathway inhibitors (vatalanib and enzastaurin) may be in theory more efficient therapies however, the lack of specificity of many of the protein tyrosine kinase inhibitors has led to unexpected dose-limiting toxicities [30]. Unfortunately, most studies with such compounds, apart from few exceptions, have proven ineffective. For example, a phase II trial of combination of imatinib mesylate, an ATP-mimetic, tyrosine kinase inhibitor, plus hydroxyurea, showed good tolerance but only moderate activity in some patients with recurrent AG [31]. Similarly, administration of gefitinib (250 mg/d), an EGFR inhibitor, after first-line chemotherapy showed limited activity in patients with recurrent gliomas [32]. However, the maximum tolerated dose of gefitinib could be 500 to $1000 \mathrm{mg} / \mathrm{kg}$ depending on the concomitant use of non-EIAEDs or EIAEDs respectively [33]. Cetuximab, an EGFR antagonist showed limited toxicity and activity against recurrent GBM independently of the EGFR status of the tumors [34]. Overall, studies on EGFR inhibitors found no significant activity of these agents in high-grade gliomas [35]. The phase II clinical trials for recurrent glioblastoma and anaplastic glioma after temozolomide failure are depicted in tables 2 and 3 respectively.

\section{Anti-angiogenesis}

Recent research and therapy strategies have focused on understanding the mechanisms leading to the origin of tumor angiogenesis in order to develop new approaches that effectively block angiogenesis and promote tumor regression [36]. Angiogenesis can be targeted by molecules against the vascular endothelial growth factor (VEGF), or its receptor, VEGFR (small molecule tyrosine kinase inhibitors) [37]. Although antiangiogenic treatment is usually well tolerated, life-threatening complications can occur, such as thromboembolism, hemorrhage and gastrointestinal perforation [38]. 
Bevacizumab is a humanized monoclonal antibody against VEGF-A, that has been shown to have significant biologic activity in patients with recurrent GBM [29] (Table 2). Bevacizumab seems to suppress the enhancing tumor recurrence more effectively than the non-enhancing infiltrative tumor [39]. It has been shown that while antiangiogenic therapy improves PFS, it may not prolong overall survival in patients with recurrent malignant glioma [40]. Other studies have demonstrated that bevacizumab improved survival but it was unclear if it increased the invasiveness of the tumor [41]. Furthermore, if patients progressed on a regimen consisted of a combination of bevacizumab with chemotherapy, rarely responded to a second bevacizumab-containing chemotherapeutic regimen [42].

\section{Irinotecan (CPT-11)}

Irinotecan, is an inhibitor of topoisomerase I, crosses the blood-brain barrier and has antitumor activity against gliomas [43]. The activity of irinotecan may be limited though with the concomitant administration of enzyme-inducing antiepileptic drugs (EIAEDs), since the pharmacokinetic studies indicated that the total body clearance of irinotecan is markedly enhanced and the maximum tolerated dose is increased 3.5 times in this study population [44]. Cloughesy et al. reported in two studies with irinotecan (CPT-11) activity against recurrent glioma especially with escalating doses suggesting that patients on EIAEDs may be underdosed [45]. However, Prados et al. failed to show such an association but the CPT-11 dose in patients that received EIAEDs was $750 \mathrm{mg} / \mathrm{m} 2$, lower to the maximum of 1700 $\mathrm{mg} / \mathrm{m} 2$ that was used in the previous study [46].

\section{Thalidomide}

Thalidomide, an antiangiogenic agent, has been considered a therapeutic option for patients with recurrent GBM after failure of other more active chemotherapeutic drugs, since it is 
generally well tolerated [47]. However, thalidomide as a single agent had very limited antitumor activity in patients with recurrent malignant gliomas [48].

\section{Fotemustine}

Fotemustine, a third generation chloroethylnitrosourea given to recurrent glioma patients after TMZ failure showed very promising results and limited toxicity in three recent studies from Italy [49-51]. In addition, like other alkylating agents, fotemustine appears more effective in patients with O6-methylguanine-DNA methyltransferase (MGMT) gene promoter methylation [49].

\section{Retinoids}

Retinoic acid, a synthetic analog of vitamin A, has multiple biologic effects against malignant gliomas and may be suitable as a maintenance therapy for patients that enter a remission after a primary treatment [52]. An earlier study of cis-retinoic acid (cRA) in recurrent glioma had indicated activity of this agent especially in GBMs [53]. However, a retrospective analysis of 82 patients with recurrent GBM, most of whom had been previously heavily treated with chemotherapy showed modest activity with cRA with response and stable disease of $45 \%$, a median PFS of 19 wks, but in the subset of $11 \%$ who responded, the median PFS was 59 weeks [54]. Another synthetic retinoid derivative, fenretinide, has been inactive in a phase II trial of recurrent malignant glioma [55]. Similar results were obtained with all-trans-retinoic acid (tretinoin) [56].

\section{Combination chemotherapy}

\section{Bevacizumab and irinotecan}

A combination of bevacizumab at $10-15 \mathrm{mg} / \mathrm{kg}$ every 3 weeks with irinotecan at $125-340$ $\mathrm{mg} / \mathrm{m} 2$ depended on the use or not of EIAEDs and administered at various schedules showed 
significant activity in anaplastic glioma patients with PFS6 of 55\% and median OS of 65 weeks [57]. Activity of this regimen with acceptable toxicity was also documented in multiple phase II trials of only GBM patients [58,59] or studies that combined a mixture of recurrent GBM and AG patients [60-63].

\section{Other irinotecan-based combinations}

Puduvalli et al. reported that a combination of CPT-11 with the anti-angiogenesis agent thalidomide resulted in potentially promising results in 32 previously treated GBM patients, $83.8 \%$ of whom had temozolomide-based chemotherapies. The PFS6 in this study was $14 \%$ and the median overall survival 30 weeks. However, in that study there were 4 deaths, 2 of them possibly due to treatment-related toxicity [64]. A smaller study in 16 patients with recurrent GBM using the same agents failed to show any additional benefit from the addition of thalidomide to irinotecan [65]. Combination of CPT-11 with VM-26 a topoisomerase II inhibitor showed no synergy between the 2 drugs and the results were comparable to results when each drug used individually [66]

In a phase I study the combination of BCNU with escalating dose of weekly administered CPT-11 was evaluated. From this study it was determined that, the recommended CPT-11 dose for patients on EIAEDs was $125 \mathrm{mg} / \mathrm{m} 2$ and for patients not on EIAEDs it was $225 \mathrm{mg} / \mathrm{m} 2$ [67]. However, a phase II trial employing such a combination resulted in comparable results to that of CPT-11 alone and increased toxicity [68]. Similarly, ACNU, another nitrosourea given alone or in combination with teniposide or cytarabine in patients with GBM after TMZ failure resulted in limited activity and considerable toxicity [69]. The combination of CPT-11 and celecoxib, a selective COX-2 inhibitor was well tolerated and had a marginal activity against heavily pretreated recurrent glioma (mostly GBM) patients with PFS6 of $25.1 \%$ [70]. 


\section{Other chemotherapeutic combinations}

Addition of metronomic etoposide in bevacizumab treated patients with recurrent glioma had no additional benefit compared to bevacizumab alone but resulted in increased toxicity [71]. Combination of carboplatin and high-dose tamoxifen in a mixture of patients with recurrent malignant gliomas of various histologies showed a median OS of 56 weeks similar to other active regimens and equivalent to those found using tamoxifen as monotherapy [72]. Use of pegylated liposomal doxorubicin in order to improve better penetration through the bloodbrain barrier, alone or in combination with high dose tamoxifen resulted in PFS6 of 15\%, and median TTP of 17 weeks, suggesting moderate effectiveness in patients with recurrent highgrade glioma [73]. Combination of carboplatin at a dose of AUC $6 \mathrm{mg} \mathrm{x} \mathrm{ml/min} \mathrm{administered}$ every 28 days, and erlotinib $150 \mathrm{mg} / \mathrm{d}$ had modest activity with median PFS of 9 weeks, PFS6 of $14 \%$, and median OS of 30 weeks [74].

Nitrosourea combinations have long been popular and efficacious, although considerably more toxic than temozolomide-based treatments. Lomustine alone [75] or in combination with other agents [76] has demonstrated activity against recurrent GBM after temozolomide failure. Prior to temozolomide, a chemotherapy combination was developed called TPCH (6-thioguanine, procarbazine, lomustine and hydroxyurea) and was created to increase tumor cell kill and, hopefully, to reduce repair of DNA damage. The therapy was active against previously-treated recurrent anaplastic glioma but less so against glioblastoma [77]. More recently, another combination chemotherapy protocol was developed called TCCC (6-thioguanine, lomustine or temozolomide, capectabine, celecoxib) and was designed to be used for patients failing either temozolomide (lomustine arm) or lomustine (temozolomide arm). The vast majority of patients were treated on the lomustine arm and, like the prior TPCH therapy, glioblastoma patients did not do as well as the anaplastic glioma 
patients that had combined response and stable disease rate of $68 \%$ with a PFS at 12 months of $44 \%$ [78].

\section{Association of certain genetic abnormalities and response to chemotherapy}

$\mathrm{O}(6)$-methylguanine-DNA methyltransferase (MGMT), is a DNA repair enzyme that is frequently up-regulated in gliomas, rendering alkylating treatment insufficient [79]. Methylation and silencing of MGMT promoter may be a favorable prognostic factor in patients with glioblastoma treated with alkylating agents [80]. Thus, in glioma patients if antiepileptic medication is needed, use of levetiracetam, a potent inhibitor of MGMT, may sensitize glioma cells to alkylating agents [81]. Furthermore, clinical trials to deplete MGMT by O-6-benzylguanine, a noncytotoxic substrate of this enzyme, in combination with alkylating agents are in progress $[82,83]$.

In tumors of oligodendroglial origin the $-1 \mathrm{p} /-19 \mathrm{q}$ genotype may predict response to cytotoxic chemotherapy and favorable outcome [84]. However, the presence of polysomy for chromosomes 1 and 19 in anaplastic oligodendrogliomas with concurrent deletion of $1 \mathrm{p} / 19 \mathrm{q}$ is a marker of early recurrence [85]. Irinotecan as single agent in patients with recurrent, TMZ-refractory, 1p19q co-deleted, anaplastic oligodendroglioma showed only modest effect [86], but improved activity with a combination of bevacizumab and irinotecan [87], or bevacizumab alone [88].

\section{Future directions}

Use of various dietary and nutraceutical approaches in patients with gliomas as adjuncts to standard therapies might prove to be beneficial for patients with recurrent gliomas. These agents include certain natural dietary components such as phytoestrogens and flavonoids, methionine restriction which may modulate MGMT activity and polyamine activity, antiinflammatory drugs, and certain polyunsaturated fatty acids such as gamma-linolenic acid 
(GLA) that may exert antineoplastic activity against gliomas without harming normal cells [89]. For example, intratumoral administration of GLA in 9 patients with recurrent GBM showed some effect and no significant side effects suggesting that high doses of GLA should be investigated in subsequent studies [90]. Similarly, eflornithine (DFMO), an irreversible inhibitor of ornithine decarboxylase, the first enzyme in polyamine synthesis, has shown activity against gliomas as a single agent and in combination with cytotoxic drugs [91-93]. In patients with recurrent glioma and epilepsy, combination of chemotherapy with antiepileptic drugs that demonstrate antineoplastic activities might offer an additional benefit [94].

Other potential useful approaches may include use of dendritic cell vaccines [95], and gene therapy, virotherapy or stem cells as adjuncts to conventional therapies for gliomas [96]. Replication-incompetent or competent viruses can be used either as gene delivery vehicles to gliomas or to induce oncolysis and avoid damage of the adjacent normal cells [97,96]. Similar approach consists of the use of stem cells for more efficient delivery of genetic material to glioma cells. Continuing research in improvement of gene transfer efficiency and stem cell technology may overcome various safety issues, and open new avenues in the management of gliomas in the future.

\section{Conclusion}

The management of newly diagnosed malignant gliomas include maximal surgery, postoperative radiation therapy and, commonly, adjuvant chemotherapy with TMZ. At recurrence, patients that did not receive adjuvant $\mathrm{TMZ}$ chemotherapy should probably receive a TMZ-based chemotherapy. Based on our personal objective evaluation of the published phase II trials, for patients that do not participate in phase II trials, we recommend the following chemotherapies after TMZ failure in order of priority (Figure 1): In patients with adequate bone marrow reserve and methylated MGMT status (likely sensitive to alkylating 
agents), nitrosourea (fotemustine, lomustine), bevacizumab/irinotecan and cis-retinoic acid. In patients with poor bone marrow reserve and methylated MGMT status, bevacizumab alone should be used followed by cis-retinoic acid. In patients with adequate bone marrow reserve and unmethylated MGMT (likely resistant to alkylating agents), bevacizumab/irinotecan followed by cRA, although TPCH or TCCC-like treatments might still have activity in about $30 \%$ of patients [77] could be used. In patients with poor bone marrow reserve and unmethylated MGMT, bevacizumab alone followed by cis-retinoic acid is recommended. Future studies employing dietary and nutraceutical approaches, tumor vaccines, gene therapy, virotherapy and stem cells may be proven to be useful as adjuncts to standard chemotherapies in order to improve the therapeutic benefit and prolong survival. 


\section{References}

1. Levin VA (1999) Chemotherapy for brain tumors of astrocytic and oligodendroglial lineage: the past decade and where we are heading. Neuro Oncol 1 (1):69-80

2. Alexiou GA, Goussia A, Kyritsis AP, Tsiouris S, Ntoulia A, Malamou-Mitsi V, Voulgaris S, Fotopoulos AD Influence of Glioma's Multidrug Resistance Phenotype on (99m)Tc-Tetrofosmin Uptake. Mol Imaging Biol. 2010 Jun 15. [Epub ahead of print] doi:10.1007/s11307-010-0369-y

3. Kyritsis AP, Zhang B, Zhang W, Xiao M, Takeshima H, Bondy ML, Cunningham JE, Levin VA, Bruner J (1996) Mutations of the p16 gene in gliomas. Oncogene 12 (1):6367

4. Gousias K, Markou M, Arzoglou V, Voulgaris S, Vartholomatos G, Kostoula A, Voulgari P, Polyzoidis K, Kyritsis AP (2010) Frequent abnormalities of the immune system in gliomas and correlation with the WHO grading system of malignancy. $\mathrm{J}$ Neuroimmunol 226 (1-2):136-142. doi:S0165-5728(10)00211-0 [pii] 10.1016/j.jneuroim.2010.05.027

5. Hadjipanayis CG, Van Meir EG (2009) Tumor initiating cells in malignant gliomas: biology and implications for therapy. J Mol Med 87 (4):363-374. doi:10.1007/s00109009-0440-9

6. Kargiotis O, Geka A, Rao JS, Kyritsis AP (2010) Effects of irradiation on tumor cell survival, invasion and angiogenesis. J Neurooncol 100 (3):323-338. doi:10.1007/s11060-010-0199-4

7. Yung WK (2000) Temozolomide in malignant gliomas. Semin Oncol 27 (3 Suppl 6):2734

8. Stupp R, Mason WP, van den Bent MJ, Weller M, Fisher B, Taphoorn MJ, Belanger K, Brandes AA, Marosi C, Bogdahn U, Curschmann J, Janzer RC, Ludwin SK, Gorlia T, 
Allgeier A, Lacombe D, Cairncross JG, Eisenhauer E, Mirimanoff RO (2005)

Radiotherapy plus concomitant and adjuvant temozolomide for glioblastoma. N Engl J Med 352 (10):987-996. doi:352/10/987 [pii]

10.1056/NEJMoa043330

9. Stupp R, Hegi ME, Mason WP, van den Bent MJ, Taphoorn MJ, Janzer RC, Ludwin SK, Allgeier A, Fisher B, Belanger K, Hau P, Brandes AA, Gijtenbeek J, Marosi C, Vecht CJ, Mokhtari K, Wesseling P, Villa S, Eisenhauer E, Gorlia T, Weller M, Lacombe D, Cairncross JG, Mirimanoff RO (2009) Effects of radiotherapy with concomitant and adjuvant temozolomide versus radiotherapy alone on survival in glioblastoma in a randomised phase III study: 5-year analysis of the EORTC-NCIC trial. Lancet Oncol 10 (5):459-466. doi:S1470-2045(09)70025-7 [pii] $10.1016 / \mathrm{S} 1470-2045(09) 70025-7$

10. Alexiou GA, Tsiouris S, Kyritsis AP, Voulgaris S, Argyropoulou MI, Fotopoulos AD (2009) Glioma recurrence versus radiation necrosis: accuracy of current imaging modalities. J Neurooncol 95 (1):1-11. doi:10.1007/s11060-009-9897-1

11. Alexiou GA, Fotopoulos AD, Papadopoulos A, Kyritsis AP, Polyzoidis KS, Tsiouris S (2007) Evaluation of brain tumor recurrence by (99m)Tc-tetrofosmin SPECT: a prospective pilot study. Ann Nucl Med 21 (5):293-298. doi:10.1007/s12149-007-0027-x

12. Kaplan WD, Takvorian T, Morris JH, Rumbaugh CL, Connolly BT, Atkins HL (1987) Thallium-201 brain tumor imaging: a comparative study with pathologic correlation. J Nucl Med 28 (1):47-52

13. Kumar AJ, Leeds NE, Fuller GN, Van Tassel P, Maor MH, Sawaya RE, Levin VA (2000) Malignant gliomas: MR imaging spectrum of radiation therapy- and chemotherapy-induced necrosis of the brain after treatment. Radiology 217 (2):377-384 
14. Wong ET, Jackson EF, Hess KR, Schomer DF, Hazle JD, Kyritsis AP, Jaeckle KA, Yung WK, Levin VA, Leeds NE (1998) Correlation between dynamic MRI and outcome in patients with malignant gliomas. Neurology 50 (3):777-781

15. Yung WK, Albright RE, Olson J, Fredericks R, Fink K, Prados MD, Brada M, Spence A, Hohl RJ, Shapiro W, Glantz M, Greenberg H, Selker RG, Vick NA, Rampling R, Friedman H, Phillips P, Bruner J, Yue N, Osoba D, Zaknoen S, Levin VA (2000) A phase II study of temozolomide vs. procarbazine in patients with glioblastoma multiforme at first relapse. Br J Cancer 83 (5):588-593. doi:10.1054/bjoc.2000.1316 S0007092000913168 [pii]

16. Yung WK, Prados MD, Yaya-Tur R, Rosenfeld SS, Brada M, Friedman HS, Albright R, Olson J, Chang SM, O'Neill AM, Friedman AH, Bruner J, Yue N, Dugan M, Zaknoen S, Levin VA (1999) Multicenter phase II trial of temozolomide in patients with anaplastic astrocytoma or anaplastic oligoastrocytoma at first relapse. Temodal Brain Tumor Group. J Clin Oncol 17 (9):2762-2771

17. Brandes AA, Tosoni A, Cavallo G, Bertorelle R, Gioia V, Franceschi E, Biscuola M, Blatt V, Crino L, Ermani M (2006) Temozolomide 3 weeks on and 1 week off as firstline therapy for recurrent glioblastoma: phase II study from gruppo italiano cooperativo di neuro-oncologia (GICNO). Br J Cancer 95 (9):1155-1160. doi:6603376 [pii] 10.1038/sj.bjc. 6603376

18. Franceschi E, Omuro AM, Lassman AB, Demopoulos A, Nolan C, Abrey LE (2005) Salvage temozolomide for prior temozolomide responders. Cancer 104 (11):2473-2476. doi:10.1002/cncr.21564

19. Wick W, Platten M, Weller M (2009) New (alternative) temozolomide regimens for the treatment of glioma. Neuro Oncol 11 (1):69-79. doi:15228517-2008-078 [pii] $10.1215 / 15228517-2008-078$ 
20. Perry JR, Belanger K, Mason WP, Fulton D, Kavan P, Easaw J, Shields C, Kirby S, Macdonald DR, Eisenstat DD, Thiessen B, Forsyth P, Pouliot JF (2010) Phase II trial of continuous dose-intense temozolomide in recurrent malignant glioma: RESCUE study. $\mathbf{J}$ Clin Oncol 28 (12):2051-2057. doi:JCO.2009.26.5520 [pii]

10.1200/JCO.2009.26.5520

21. Hess KR, Wong ET, Jaeckle KA, Kyritsis AP, Levin VA, Prados MD, Yung WK (1999) Response and progression in recurrent malignant glioma. Neuro Oncol 1 (4):282-288

22. Wong ET, Hess KR, Gleason MJ, Jaeckle KA, Kyritsis AP, Prados MD, Levin VA, Yung WK (1999) Outcomes and prognostic factors in recurrent glioma patients enrolled onto phase II clinical trials. J Clin Oncol 17 (8):2572-2578

23. Levin VA, Ictech S, Hess KR (2007) Impact of phase II trials with progression-free survival as end-points on survival-based phase III studies in patients with anaplastic gliomas. BMC Cancer 7:106. doi:1471-2407-7-106 [pii]

$10.1186 / 1471-2407-7-106$

24. Ballman KV, Buckner JC, Brown PD, Giannini C, Flynn PJ, LaPlant BR, Jaeckle KA (2007) The relationship between six-month progression-free survival and 12-month overall survival end points for phase II trials in patients with glioblastoma multiforme. Neuro Oncol 9 (1):29-38. doi:15228517-2006-025 [pii]

$10.1215 / 15228517-2006-025$

25. Lamborn KR, Yung WK, Chang SM, Wen PY, Cloughesy TF, DeAngelis LM, Robins HI, Lieberman FS, Fine HA, Fink KL, Junck L, Abrey L, Gilbert MR, Mehta M, Kuhn JG, Aldape KD, Hibberts J, Peterson PM, Prados MD (2008) Progression-free survival: an important end point in evaluating therapy for recurrent high-grade gliomas. Neuro Oncol 10 (2):162-170. doi:15228517-2007-062 [pii] 
$10.1215 / 15228517-2007-062$

26. van den Bent MJ, Vogelbaum MA, Wen PY, Macdonald DR, Chang SM (2009) End point assessment in gliomas: novel treatments limit usefulness of classical Macdonald's Criteria. J Clin Oncol 27 (18):2905-2908. doi:JCO.2009.22.4998 [pii] 10.1200/JCO.2009.22.4998

27. Vos MJ, Uitdehaag BM, Barkhof F, Heimans JJ, Baayen HC, Boogerd W, Castelijns JA, Elkhuizen PH, Postma TJ (2003) Interobserver variability in the radiological assessment of response to chemotherapy in glioma. Neurology 60 (5):826-830

28. Prados M, Cloughesy T, Samant M, Fang L, Wen PY, Mikkelsen T, Schiff D, Abrey LE, Yung WK, Paleologos N, Nicholas MK, Jensen R, Vredenburgh J, Das A, Friedman HS (2010) Response as a predictor of survival in patients with recurrent glioblastoma treated with bevacizumab. Neuro Oncol 13:143-151. doi:noq151 [pii] 10.1093/neuonc/noq151

29. Kreisl TN, Kim L, Moore K, Duic P, Royce C, Stroud I, Garren N, Mackey M, Butman JA, Camphausen K, Park J, Albert PS, Fine HA (2009) Phase II trial of single-agent bevacizumab followed by bevacizumab plus irinotecan at tumor progression in recurrent glioblastoma. J Clin Oncol 27 (5):740-745. doi:JCO.2008.16.3055 [pii] 10.1200/JCO.2008.16.3055

30. Omuro AM (2008) Exploring multi-targeting strategies for the treatment of gliomas. Curr Opin Investig Drugs 9 (12):1287-1295

31. Desjardins A, Quinn JA, Vredenburgh JJ, Sathornsumetee S, Friedman AH, Herndon JE, McLendon RE, Provenzale JM, Rich JN, Sampson JH, Gururangan S, Dowell JM, Salvado A, Friedman HS, Reardon DA (2007) Phase II study of imatinib mesylate and hydroxyurea for recurrent grade III malignant gliomas. J Neurooncol 83 (1):53-60. doi:10.1007/s11060-006-9302-2 
32. Franceschi E, Cavallo G, Lonardi S, Magrini E, Tosoni A, Grosso D, Scopece L, Blatt V, Urbini B, Pession A, Tallini G, Crino L, Brandes AA (2007) Gefitinib in patients with progressive high-grade gliomas: a multicentre phase II study by Gruppo Italiano Cooperativo di Neuro-Oncologia (GICNO). Br J Cancer 96 (7):1047-1051. doi:6603669 [pii]

10.1038/sj.bjc.6603669

33. Reardon DA, Quinn JA, Vredenburgh JJ, Gururangan S, Friedman AH, Desjardins A, Sathornsumetee S, Herndon JE, 2nd, Dowell JM, McLendon RE, Provenzale JM, Sampson JH, Smith RP, Swaisland AJ, Ochs JS, Lyons P, Tourt-Uhlig S, Bigner DD, Friedman HS, Rich JN (2006) Phase 1 trial of gefitinib plus sirolimus in adults with recurrent malignant glioma. Clin Cancer Res 12 (3 Pt 1):860-868. doi:12/3/860 [pii] 10.1158/1078-0432.CCR-05-2215

34. Neyns B, Sadones J, Joosens E, Bouttens F, Verbeke L, Baurain JF, D'Hondt L, Strauven T, Chaskis C, In't Veld P, Michotte A, De Greve J (2009) Stratified phase II trial of cetuximab in patients with recurrent high-grade glioma. Ann Oncol 20 (9):15961603. doi:mdp032 [pii]

10.1093/annonc/mdp032

35. Brandes AA, Franceschi E, Tosoni A, Hegi ME, Stupp R (2008) Epidermal growth factor receptor inhibitors in neuro-oncology: hopes and disappointments. Clin Cancer Res 14 (4):957-960. doi:14/4/957 [pii]

10.1158/1078-0432.CCR-07-1810

36. Kargiotis O, Rao JS, Kyritsis AP (2006) Mechanisms of angiogenesis in gliomas. J Neurooncol 78 (3):281-293. doi:10.1007/s11060-005-9097-6

37. Chamberlain MC, Raizer J (2009) Antiangiogenic therapy for high-grade gliomas. CNS Neurol Disord Drug Targets 8 (3):184-194 
38. Norden AD, Drappatz J, Ciampa AS, Doherty L, LaFrankie DC, Kesari S, Wen PY (2009) Colon perforation during antiangiogenic therapy for malignant glioma. Neuro Oncol 11 (1):92-95. doi:15228517-2008-071 [pii]

$10.1215 / 15228517-2008-071$

39. Norden AD, Young GS, Setayesh K, Muzikansky A, Klufas R, Ross GL, Ciampa AS, Ebbeling LG, Levy B, Drappatz J, Kesari S, Wen PY (2008) Bevacizumab for recurrent malignant gliomas: efficacy, toxicity, and patterns of recurrence. Neurology 70 (10):779-787. doi:70/10/779 [pii]

10.1212/01.wnl.0000304121.57857.38

40. Norden AD, Drappatz J, Muzikansky A, David K, Gerard M, McNamara MB, Phan P, Ross A, Kesari S, Wen PY (2009) An exploratory survival analysis of anti-angiogenic therapy for recurrent malignant glioma. J Neurooncol 92 (2):149-155. doi:10.1007/s11060-008-9745-8

41. Narayana A, Kelly P, Golfinos J, Parker E, Johnson G, Knopp E, Zagzag D, Fischer I, Raza S, Medabalmi P, Eagan P, Gruber ML (2009) Antiangiogenic therapy using bevacizumab in recurrent high-grade glioma: impact on local control and patient survival. J Neurosurg 110 (1):173-180. doi:10.3171/2008.4.17492

42. Quant EC, Norden AD, Drappatz J, Muzikansky A, Doherty L, Lafrankie D, Ciampa A, Kesari S, Wen PY (2009) Role of a second chemotherapy in recurrent malignant glioma patients who progress on bevacizumab. Neuro Oncol 11 (5):550-555. doi:152285172009-006 [pii]

10.1215/15228517-2009-006

43. Vredenburgh JJ, Desjardins A, Reardon DA, Friedman HS (2009) Experience with irinotecan for the treatment of malignant glioma. Neuro Oncol 11 (1):80-91. doi:15228517-2008-075 [pii] 
$10.1215 / 15228517-2008-075$

44. Gilbert MR, Supko JG, Batchelor T, Lesser G, Fisher JD, Piantadosi S, Grossman S (2003) Phase I clinical and pharmacokinetic study of irinotecan in adults with recurrent malignant glioma. Clin Cancer Res 9 (8):2940-2949

45. Cloughesy TF, Filka E, Kuhn J, Nelson G, Kabbinavar F, Friedman H, Miller LL, Elfring GL (2003) Two studies evaluating irinotecan treatment for recurrent malignant glioma using an every-3-week regimen. Cancer 97 (9 Suppl):2381-2386. doi:10.1002/cncr.11306

46. Prados MD, Lamborn K, Yung WK, Jaeckle K, Robins HI, Mehta M, Fine HA, Wen PY, Cloughesy T, Chang S, Nicholas MK, Schiff D, Greenberg H, Junck L, Fink K, Hess K, Kuhn J (2006) A phase 2 trial of irinotecan (CPT-11) in patients with recurrent malignant glioma: a North American Brain Tumor Consortium study. Neuro Oncol 8 (2):189-193. doi:15228517-2005-010 [pii] $10.1215 / 15228517-2005-010$

47. Morabito A, Fanelli M, Carillio G, Gattuso D, Sarmiento R, Gasparini G (2004) Thalidomide prolongs disease stabilization after conventional therapy in patients with recurrent glioblastoma. Oncol Rep 11 (1):93-95

48. Fine HA, Figg WD, Jaeckle K, Wen PY, Kyritsis AP, Loeffler JS, Levin VA, Black PM, Kaplan R, Pluda JM, Yung WK (2000) Phase II trial of the antiangiogenic agent thalidomide in patients with recurrent high-grade gliomas. J Clin Oncol 18 (4):708-715

49. Fabi A, Metro G, Russillo M, Vidiri A, Carapella CM, Maschio M, Cognetti F, Jandolo B, Mirri MA, Sperduti I, Telera S, Carosi M, Pace A (2009) Treatment of recurrent malignant gliomas with fotemustine monotherapy: impact of dose and correlation with MGMT promoter methylation. BMC Cancer 9:101. doi:1471-2407-9-101 [pii] $10.1186 / 1471-2407-9-101$ 
50. Fabrini MG, Silvano G, Lolli I, Perrone F, Marsella A, Scotti V, Cionini L (2009) A multi-institutional phase II study on second-line Fotemustine chemotherapy in recurrent glioblastoma. J Neurooncol 92 (1):79-86. doi:10.1007/s11060-008-9739-6

51. Scoccianti S, Detti B, Sardaro A, Iannalfi A, Meattini I, Leonulli BG, Borghesi S, Martinelli F, Bordi L, Ammannati F, Biti G (2008) Second-line chemotherapy with fotemustine in temozolomide-pretreated patients with relapsing glioblastoma: a single institution experience. Anticancer Drugs 19 (6):613-620.

doi:10.1097/CAD.0b013e3283005075

00001813-200807000-00008 [pii]

52. Wismeth C, Hau P, Fabel K, Baumgart U, Hirschmann B, Koch H, Jauch T, Grauer O, Drechsel L, Brawanski A, Bogdahn U, Steinbrecher A (2004) Maintenance therapy with 13-cis retinoid acid in high-grade glioma at complete response after first-line multimodal therapy--a phase-II study. J Neurooncol 68 (1):79-86

53. Yung WK, Kyritsis AP, Gleason MJ, Levin VA (1996) Treatment of recurrent malignant gliomas with high-dose 13-cis-retinoic acid. Clin Cancer Res 2 (12):19311935

54. See SJ, Levin VA, Yung WK, Hess KR, Groves MD (2004) 13-cis-retinoic acid in the treatment of recurrent glioblastoma multiforme. Neuro Oncol 6 (3):253-258. doi: $10.1215 / \mathrm{S} 1152851703000607$

55. Puduvalli VK, Yung WK, Hess KR, Kuhn JG, Groves MD, Levin VA, Zwiebel J, Chang SM, Cloughesy TF, Junck L, Wen P, Lieberman F, Conrad CA, Gilbert MR, Meyers CA, Liu V, Mehta MP, Nicholas MK, Prados M (2004) Phase II study of fenretinide (NSC 374551) in adults with recurrent malignant gliomas: A North American Brain Tumor Consortium study. J Clin Oncol 22 (21):4282-4289. doi:22/21/4282 [pii] 
10.1200/JCO.2004.09.096

56. Kaba SE, Kyritsis AP, Conrad C, Gleason MJ, Newman R, Levin VA, Yung WK (1997) The treatment of recurrent cerebral gliomas with all-trans-retinoic acid (tretinoin). J Neurooncol 34 (2):145-151

57. Desjardins A, Reardon DA, Herndon JE, 2nd, Marcello J, Quinn JA, Rich JN, Sathornsumetee S, Gururangan S, Sampson J, Bailey L, Bigner DD, Friedman AH, Friedman HS, Vredenburgh JJ (2008) Bevacizumab plus irinotecan in recurrent WHO grade 3 malignant gliomas. Clin Cancer Res 14 (21):7068-7073. doi:14/21/7068 [pii] 10.1158/1078-0432.CCR-08-0260

58. Vredenburgh JJ, Desjardins A, Herndon JE, 2nd, Marcello J, Reardon DA, Quinn JA, Rich JN, Sathornsumetee S, Gururangan S, Sampson J, Wagner M, Bailey L, Bigner DD, Friedman AH, Friedman HS (2007) Bevacizumab plus irinotecan in recurrent glioblastoma multiforme. J Clin Oncol 25 (30):4722-4729. doi:25/30/4722 [pii] 10.1200/JCO.2007.12.2440

59. Friedman HS, Prados MD, Wen PY, Mikkelsen T, Schiff D, Abrey LE, Yung WK, Paleologos N, Nicholas MK, Jensen R, Vredenburgh J, Huang J, Zheng M, Cloughesy T (2009) Bevacizumab alone and in combination with irinotecan in recurrent glioblastoma. J Clin Oncol 27 (28):4733-4740. doi:JCO.2008.19.8721 [pii] 10.1200/JCO.2008.19.8721

60. Vredenburgh JJ, Desjardins A, Herndon JE, 2nd, Dowell JM, Reardon DA, Quinn JA, Rich JN, Sathornsumetee S, Gururangan S, Wagner M, Bigner DD, Friedman AH, Friedman HS (2007) Phase II trial of bevacizumab and irinotecan in recurrent malignant glioma. Clin Cancer Res 13 (4):1253-1259. doi:13/4/1253 [pii] 10.1158/1078-0432.CCR-06-2309 
61. Kang TY, Jin T, Elinzano H, Peereboom D (2008) Irinotecan and bevacizumab in progressive primary brain tumors, an evaluation of efficacy and safety. J Neurooncol 89 (1):113-118. doi:10.1007/s11060-008-9599-0

62. Poulsen HS, Grunnet K, Sorensen M, Olsen P, Hasselbalch B, Nelausen K, Kosteljanetz M, Lassen U (2009) Bevacizumab plus irinotecan in the treatment patients with progressive recurrent malignant brain tumours. Acta Oncol 48 (1):52-58. doi:905944617 [pii] $10.1080 / 02841860802537924$

63. Bokstein F, Shpigel S, Blumenthal DT (2008) Treatment with bevacizumab and irinotecan for recurrent high-grade glial tumors. Cancer 112 (10):2267-2273. doi:10.1002/cncr.23401

64. Puduvalli VK, Giglio P, Groves MD, Hess KR, Gilbert MR, Mahankali S, Jackson EF, Levin VA, Conrad CA, Hsu SH, Colman H, de Groot JF, Ritterhouse MG, Ictech SE, Yung WK (2008) Phase II trial of irinotecan and thalidomide in adults with recurrent glioblastoma multiforme. Neuro Oncol 10 (2):216-222. doi:15228517-2007-060 [pii] $10.1215 / 15228517-2007-060$

65. Fadul CE, Kingman LS, Meyer LP, Cole BF, Eskey CJ, Rhodes CH, Roberts DW, Newton HB, Pipas JM (2008) A phase II study of thalidomide and irinotecan for treatment of glioblastoma multiforme. J Neurooncol 90 (2):229-235. doi:10.1007/s11060-008-9655-9

66. Feun LG, Marini A, Landy H, Markoe A, Heros D, Robles C, Herrera C, Savaraj N (2007) Clinical trial of CPT-11 and VM-26/VP-16 for patients with recurrent malignant brain tumors. J Neurooncol 82 (2):177-181. doi:10.1007/s11060-006-9261-7

67. Quinn JA, Reardon DA, Friedman AH, Rich JN, Sampson JH, Vredenburgh J, Gururangan S, Provenzale JM, Walker A, Schweitzer H, Bigner DD, Tourt-Uhlig S, 
Herndon JE, 2nd, Affronti ML, Jackson S, Allen D, Ziegler K, Bohlin C, Lentz C, Friedman HS (2004) Phase 1 trial of irinotecan plus BCNU in patients with progressive or recurrent malignant glioma. Neuro Oncol 6 (2):145-153.

doi: $10.1215 / \mathrm{S} 1152851703000498$

68. Reardon DA, Quinn JA, Rich JN, Gururangan S, Vredenburgh J, Sampson JH, Provenzale JM, Walker A, Badruddoja M, Tourt-Uhlig S, Herndon JE, 2nd, Dowell JM, Affronti ML, Jackson S, Allen D, Ziegler K, Silverman S, Bohlin C, Friedman AH, Bigner DD, Friedman HS (2004) Phase 2 trial of BCNU plus irinotecan in adults with malignant glioma. Neuro Oncol 6 (2):134-144

69. Happold C, Roth P, Wick W, Steinbach JP, Linnebank M, Weller M, Eisele G (2009) ACNU-based chemotherapy for recurrent glioma in the temozolomide era. $\mathbf{J}$ Neurooncol 92 (1):45-48. doi:10.1007/s11060-008-9728-9

70. Reardon DA, Quinn JA, Vredenburgh J, Rich JN, Gururangan S, Badruddoja M, Herndon JE, 2nd, Dowell JM, Friedman AH, Friedman HS (2005) Phase II trial of irinotecan plus celecoxib in adults with recurrent malignant glioma. Cancer 103 (2):329338. doi:10.1002/cncr.20776

71. Reardon DA, Desjardins A, Vredenburgh JJ, Gururangan S, Sampson JH, Sathornsumetee S, McLendon RE, Herndon JE, 2nd, Marcello JE, Norfleet J, Friedman AH, Bigner DD, Friedman HS (2009) Metronomic chemotherapy with daily, oral etoposide plus bevacizumab for recurrent malignant glioma: a phase II study. Br J Cancer 101 (12):1986-1994. doi:6605412 [pii] 10.1038/sj.bjc.6605412

72. Tang P, Roldan G, Brasher PM, Fulton D, Roa W, Murtha A, Cairncross JG, Forsyth PA (2006) A phase II study of carboplatin and chronic high-dose tamoxifen in patients 
with recurrent malignant glioma. J Neurooncol 78 (3):311-316. doi:10.1007/s11060005-9104-y

73. Hau P, Fabel K, Baumgart U, Rummele P, Grauer O, Bock A, Dietmaier C, Dietmaier W, Dietrich J, Dudel C, Hubner F, Jauch T, Drechsel E, Kleiter I, Wismeth C, Zellner A, Brawanski A, Steinbrecher A, Marienhagen J, Bogdahn U (2004) Pegylated liposomal doxorubicin-efficacy in patients with recurrent high-grade glioma. Cancer 100 (6):1199-1207. doi:10.1002/cncr.20073

74. de Groot JF, Gilbert MR, Aldape K, Hess KR, Hanna TA, Ictech S, Groves MD, Conrad C, Colman H, Puduvalli VK, Levin V, Yung WK (2008) Phase II study of carboplatin and erlotinib (Tarceva, OSI-774) in patients with recurrent glioblastoma. J Neurooncol 90 (1):89-97. doi:10.1007/s11060-008-9637-y

75. Wick W, Puduvalli VK, Chamberlain MC, van den Bent MJ, Carpentier AF, Cher LM, Mason W, Weller M, Hong S, Musib L, Liepa AM, Thornton DE, Fine HA Phase III study of enzastaurin compared with lomustine in the treatment of recurrent intracranial glioblastoma. J Clin Oncol 28 (7):1168-1174. doi:JCO.2009.23.2595 [pii] 10.1200/JCO.2009.23.2595

76. Ahluwalia MS 2010 Society for Neuro-Oncology Annual Meeting: a report of selected studies. Expert Rev Anticancer Ther 11 (2):161-163. doi:10.1586/era.10.227

77. Kyritsis AP, Yung WK, Jaeckle KA, Bruner J, Gleason MJ, Ictech SE, Flowers A, Levin VA (1996) Combination of 6-thioguanine, procarbazine, lomustine, and hydroxyurea for patients with recurrent malignant gliomas. Neurosurgery 39 (5):921926

78. Walbert T, Gilbert MR, Groves MD, Puduvalli VK, Alfred Yung WK, Conrad CA, Bobustuc GC, Colman H, Hsu SH, Nebiyou Bekele B, Qiao W, Levin VA (2010) Combination of 6-thioguanine, capecitabine, and celecoxib with temozolomide or 
lomustine for recurrent high-grade glioma. J Neurooncol. doi:10.1007/s11060-010$0313-7$

79. Silber JR, Blank A, Bobola MS, Ghatan S, Kolstoe DD, Berger MS (1999) O6methylguanine-DNA methyltransferase-deficient phenotype in human gliomas: frequency and time to tumor progression after alkylating agent-based chemotherapy. Clin Cancer Res 5 (4):807-814

80. Hegi ME, Diserens AC, Gorlia T, Hamou MF, de Tribolet N, Weller M, Kros JM, Hainfellner JA, Mason W, Mariani L, Bromberg JE, Hau P, Mirimanoff RO, Cairncross JG, Janzer RC, Stupp R (2005) MGMT gene silencing and benefit from temozolomide in glioblastoma. N Engl J Med 352 (10):997-1003. doi:352/10/997 [pii] 10.1056/NEJMoa043331

81. Bobustuc GC, Baker CH, Limaye A, Jenkins WD, Pearl G, Avgeropoulos NG, Konduri SD (2010) Levetiracetam enhances p53-mediated MGMT inhibition and sensitizes glioblastoma cells to temozolomide. Neuro Oncol 12 (9):917-927. doi:noq044 [pii] 10.1093/neuonc/noq044

82. Quinn JA, Desjardins A, Weingart J, Brem H, Dolan ME, Delaney SM, Vredenburgh J, Rich J, Friedman AH, Reardon DA, Sampson JH, Pegg AE, Moschel RC, Birch R, McLendon RE, Provenzale JM, Gururangan S, Dancey JE, Maxwell J, Tourt-Uhlig S, Herndon JE, 2nd, Bigner DD, Friedman HS (2005) Phase I trial of temozolomide plus O6-benzylguanine for patients with recurrent or progressive malignant glioma. J Clin Oncol 23 (28):7178-7187. doi:23/28/7178 [pii]

10.1200/JCO.2005.06.502

83. Quinn JA, Jiang SX, Reardon DA, Desjardins A, Vredenburgh JJ, Rich JN, Gururangan S, Friedman AH, Bigner DD, Sampson JH, McLendon RE, Herndon JE, 2nd, Walker A, Friedman HS (2009) Phase II trial of temozolomide plus o6-benzylguanine in adults 
with recurrent, temozolomide-resistant malignant glioma. J Clin Oncol 27 (8):12621267. doi:JCO.2008.18.8417 [pii]

10.1200/JCO.2008.18.8417

84. Walker C, Haylock B, Husband D, Joyce KA, Fildes D, Jenkinson MD, Smith T, Broome J, du Plessis DG, Warnke PC (2006) Clinical use of genotype to predict chemosensitivity in oligodendroglial tumors. Neurology 66 (11):1661-1667. doi:66/11/1661 [pii] 10.1212/01.wnl.0000218270.12495.9a

85. Snuderl M, Eichler AF, Ligon KL, Vu QU, Silver M, Betensky RA, Ligon AH, Wen PY, Louis DN, Iafrate AJ (2009) Polysomy for chromosomes 1 and 19 predicts earlier recurrence in anaplastic oligodendrogliomas with concurrent 1p/19q loss. Clin Cancer Res 15 (20):6430-6437. doi:1078-0432.CCR-09-0867 [pii] 10.1158/1078-0432.CCR-09-0867

86. Chamberlain MC, Glantz MJ (2008) CPT-11 for recurrent temozolomide-refractory 1p19q co-deleted anaplastic oligodendroglioma. J Neurooncol 89 (2):231-238. doi:10.1007/s11060-008-9613-6

87. Taillibert S, Vincent LA, Granger B, Marie Y, Carpentier C, Guillevin R, Bellanger A, Mokhtari K, Rousseau A, Psimaras D, Dehais C, Sierra del Rio M, Meng Y, LaigleDonadey F, Hoang-Xuan K, Sanson M, Delattre JY (2009) Bevacizumab and irinotecan for recurrent oligodendroglial tumors. Neurology 72 (18):1601-1606. doi:72/18/1601 [pii] 10.1212/WNL.0b013e3181a413be

88. Chamberlain MC, Johnston S (2009) Bevacizumab for recurrent alkylator-refractory anaplastic oligodendroglioma. Cancer 115 (8):1734-1743. doi:10.1002/cncr.24179 
89. Kyritsis AP, Bondy ML, Levin VA (2011) Modulation of Glioma Risk and Progression by Dietary Nutrients and Antiinflammatory Agents. Nutr Cancer 63(2):174-84 doi:933160147 [pii]

$10.1080 / 01635581.2011 .523807$

90. Bakshi A, Mukherjee D, Banerji AK, Das UN (2003) Gamma-linolenic acid therapy of human gliomas. Nutrition 19 (4):305-309. doi:S0899900702008626 [pii]

91. Levin VA, Chamberlain MC, Prados MD, Choucair AK, Berger MS, Silver P, Seager M, Gutin PH, Davis RL, Wilson CB (1987) Phase I-II study of eflornithine and mitoguazone combined in the treatment of recurrent primary brain tumors. Cancer Treat Rep 71 (5):459-464

92. Levin VA, Hess KR, Choucair A, Flynn PJ, Jaeckle KA, Kyritsis AP, Yung WK, Prados MD, Bruner JM, Ictech S, Gleason MJ, Kim HW (2003) Phase III randomized study of postradiotherapy chemotherapy with combination alphadifluoromethylornithine-PCV versus PCV for anaplastic gliomas. Clin Cancer Res 9 (3):981-990

93. Levin VA, Uhm JH, Jaeckle KA, Choucair A, Flynn PJ, Yung WKA, Prados MD, Bruner JM, Chang SM, Kyritsis AP, Gleason MJ, Hess KR (2000) Phase III randomized study of postradiotherapy chemotherapy with alpha-difluoromethylornithineprocarbazine, N-(2-chloroethyl)-N'-cyclohexyl-N-nitrosurea, vincristine (DFMO-PCV) versus PCV for glioblastoma multiforme. Clin Cancer Res 6 (10):3878-3884

94. Kargiotis O, Markoula S, Kyritsis (2011) AP Epilepsy in the cancer patient. Cancer Chemother Pharmacol 67 (3):489-501. doi:10.1007/s00280-011-1569-0

95. Wheeler CJ (2010) Dendritic cell vaccines to combat glioblastoma. Expert Rev Neurother 10 (4):483-486. doi:10.1586/ern.10.26 
96. Kyritsis AP, Sioka C, Rao JS (2009) Viruses, gene therapy and stem cells for the treatment of human glioma. Cancer Gene Ther 16 (10):741-752. doi:cgt200952 [pii] $10.1038 /$ cgt.2009.52

97. Kargiotis O, Chetty C, Gondi CS, Tsung AJ, Dinh DH, Gujrati M, Lakka SS, Kyritsis AP, Rao JS (2008) Adenovirus-mediated transfer of siRNA against MMP-2 mRNA results in impaired invasion and tumor-induced angiogenesis, induces apoptosis in vitro and inhibits tumor growth in vivo in glioblastoma. Oncogene 27 (35):4830-4840. doi:onc2008122 [pii]

10.1038/onc.2008.122

Disclosures: None 


\section{Figure legends}

Figure 1. Algorithm for management of glioma recurrence after initial surgery, radiotherapy and temozolomide chemotherapy. Determination of $1 \mathrm{p} / 19 \mathrm{q}$ genotype status in patients with tumors of oligodendroglial origin may aid in prognosis determination. MGMT: O(6)methylguanine-DNA methyltransferase; * irinotecan or other cytotoxic agents as evidence develops from ongoing phase II trials. 
Table 1. Endpoints for evaluation of phase II clinical trials in recurrent glioma

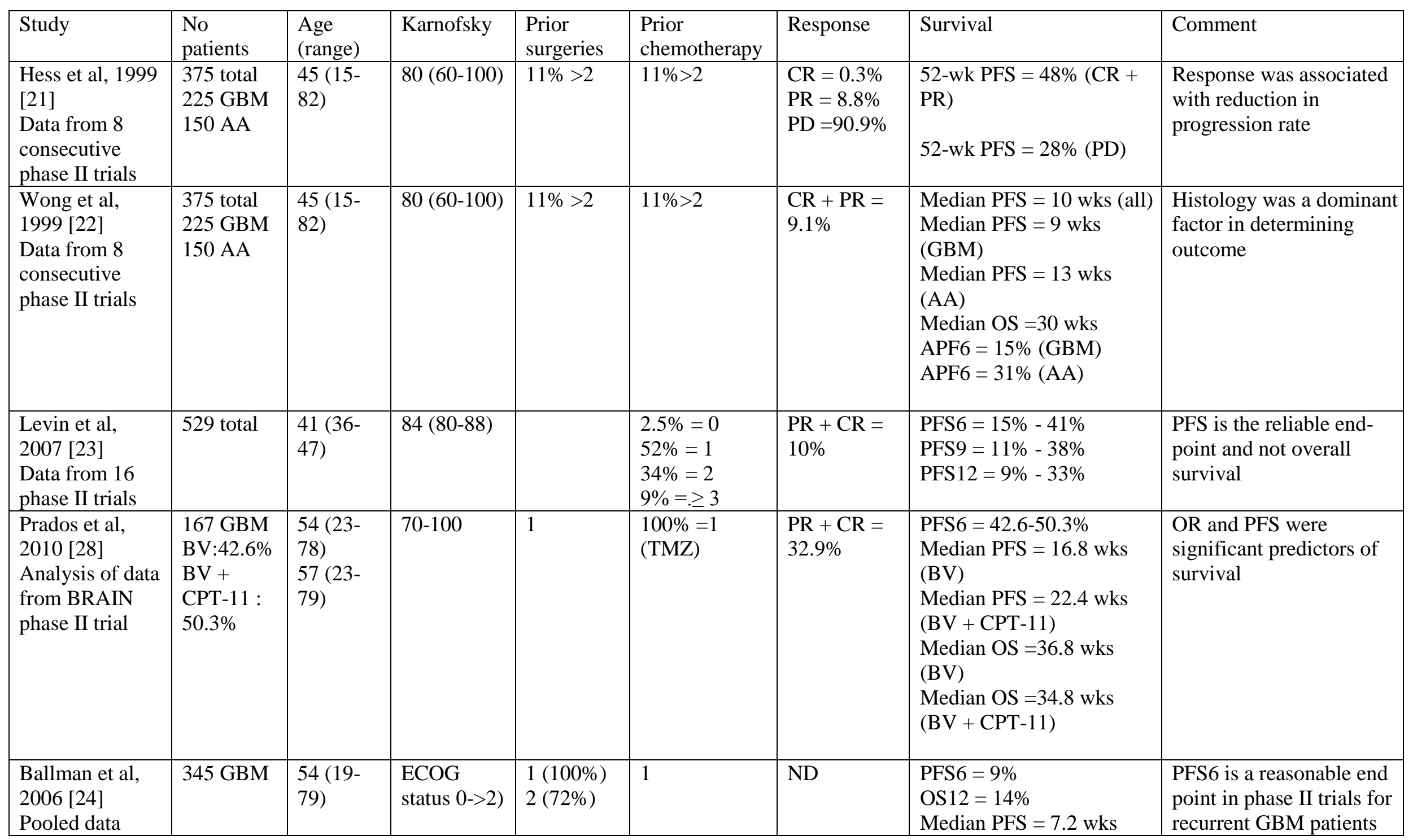




\begin{tabular}{|c|c|c|c|c|c|c|c|c|}
\hline $\begin{array}{l}\text { from } 16 \text { phase } \\
\text { II and phase III } \\
\text { trials }\end{array}$ & & & & & & & Median OS = $20 \mathrm{wks}$ & \\
\hline $\begin{array}{l}\text { Lamborn et al, } \\
2008 \text { [25] } \\
\text { Pooled data } \\
\text { from } 12 \\
\text { published phase } \\
\text { II trials }\end{array}$ & $\begin{array}{l}596 \text { total } \\
437 \mathrm{GBM} \\
159 \mathrm{AG}\end{array}$ & $\begin{array}{l}49(20- \\
84)\end{array}$ & $60-100$ & $\begin{array}{l}1(100 \%) \\
2(15 \%)\end{array}$ & $\begin{array}{l}23 \%=0 \\
51 \%=1 \\
23 \%=2 \\
3 \%=3\end{array}$ & $\begin{array}{l}\mathrm{PR}+\mathrm{CR}= \\
7 \%\end{array}$ & $\begin{array}{l}\text { AG-PFS }(9 \mathrm{wks})=53 \% \\
\text { AG-PFS }(18 \mathrm{wks})=33 \% \\
\text { AG-PFS }(26 \mathrm{wks})=28 \% \\
\text { AG-Median PFS }=15 \mathrm{wks} \\
\text { AG-Median OS }=39 \mathrm{wks} \\
\text { GBM-PFS }(9 \mathrm{wks})=44 \% \\
\text { GBM-PFS }(18 \mathrm{wks})=25 \% \\
\text { GBM-PFS }(26 \mathrm{wks})=16 \% \\
\text { GBM-Median PFS }=8 \mathrm{wks} \\
\text { GBM-Median OS }=30 \mathrm{wks}\end{array}$ & $\begin{array}{l}\text { PFS6 is a useful end point } \\
\text { in phase II trials for } \\
\text { recurrent glioma patients; } \\
\text { status at earlier time } \\
\text { points may be also useful } \\
\text { particularly in studies with } \\
\text { negative results }\end{array}$ \\
\hline
\end{tabular}

APF6: progression-free at 6 months; GBM: glioblastoma multiforme; AA: anaplastic astrocytoma; BV: bevacizumab; PFS: progression-free survival; OS: overall survival; OS12: 12-month overall survival; CR: complete response; PR: partial response; OR: objective response; PD: progressive disease; PFS6: progression-free survival at 6 months; PFS9: progression-free survival at 9 months; PFS12: progression-free survival at 12 months; ND: Not determined. 
Table 2. Results of phase II clinical trials in recurrent glioblastoma patients after temozolomide failure

\begin{tabular}{|c|c|c|c|c|c|c|c|c|}
\hline Study & Treatment & No & Toxicity levels 3/4 & $\begin{array}{c}\text { Response } \\
+ \text { Stable } \\
\text { Disease, \% }\end{array}$ & $\begin{array}{l}\text { MPFS, } \\
\text { weeks }\end{array}$ & $\begin{array}{c}\text { PFS6 } \\
(\mathbf{9 5 \%} \text { CI })\end{array}$ & $\begin{array}{c}\text { Median } \\
\text { OS, weeks }\end{array}$ & Comment \\
\hline $\begin{array}{l}\text { Franceschi et } \\
\text { al, } 2007 \text { [32] }\end{array}$ & Gefitinib & 16 & None & 17.9 & & $\begin{array}{l}12.5 \% \\
(1.6- \\
38.4 \%)\end{array}$ & $\mathrm{NC}$ & Limited activity \\
\hline $\begin{array}{l}\text { Neyns et al, } \\
2009[34]\end{array}$ & Cetuximab & 55 & $13.6 \%$ & 35.1 & 7.6 & $\begin{array}{l}7.3 \%(0- \\
14 \%)\end{array}$ & 20 & $\begin{array}{l}\text { Limited activity } \\
\text { No differences between EGFR }+ \text { and } \\
\text { EGFR - }\end{array}$ \\
\hline $\begin{array}{l}\text { Puduvalli et } \\
\text { al, } 2008[64]\end{array}$ & $\begin{array}{l}\text { CPT-11 and } \\
\text { Thalidomide }\end{array}$ & 32 & $56 \%$ & 65.6 & 13 & $\begin{array}{c}25 \%(14- \\
46 \%)\end{array}$ & 36 & CPT-11 with thalidomide is promising \\
\hline $\begin{array}{l}\text { Fadul et al, } \\
2008 \text { [65] }\end{array}$ & $\begin{array}{l}\text { CPT-11 and } \\
\text { Thalidomide }\end{array}$ & 16 & $37.5 \%$ & 18.8 & & $\begin{array}{l}19 \%(4- \\
46 \%)\end{array}$ & 41 & Comparable to CPT-11 alone \\
\hline $\begin{array}{l}\text { De Groot et } \\
\text { al, } 2008[74]\end{array}$ & $\begin{array}{l}\text { Carboplatin and } \\
\text { Erlotinib }\end{array}$ & 43 & $100 \%$ & 49.3 & 9 & $\begin{array}{l}14 \%(4- \\
24 \%)\end{array}$ & 30 & $\begin{array}{l}\text { Carboplatin with erlotinib has modest } \\
\text { activity }\end{array}$ \\
\hline $\begin{array}{l}\text { Fabrini et a, } \\
2009[50]\end{array}$ & Fotemustine & 41 & $14 \%$ & 62 & 23.6 & $\begin{array}{l}48.7 \% \\
(35.2- \\
62.2) \\
\end{array}$ & $\mathrm{NC}$ & Fotemustine was safe and effective \\
\hline $\begin{array}{l}\text { Scoccianti et } \\
\text { al, } 2008[51]\end{array}$ & Fotemustine & 27 & $14.8 \%$ & 48.1 & 22.8 & $\begin{array}{l}48.1 \% \\
(39.1- \\
57.1)\end{array}$ & 36.4 & Fotemustine was safe and effective \\
\hline $\begin{array}{l}\text { Prados et al, } \\
2006[46]\end{array}$ & CPT-11 & 38 & $\begin{array}{l}\text { On EIAED = 0 } \\
(\text { Not on EIAED })= \\
19.6 \%\end{array}$ & $\mathrm{NC}$ & & $\begin{array}{l}15.7 \%(7- \\
31 \%)\end{array}$ & & Ineffective \\
\hline $\begin{array}{l}\text { Reardon et } \\
\text { al, } 2005[70]\end{array}$ & $\begin{array}{l}\text { CPT- } 11 \text { and } \\
\text { celecoxib }\end{array}$ & 33 & $\begin{array}{l}\text { On EIAED }=0 \\
(\text { Not on EIAED })= \\
21.6 \%\end{array}$ & 55.8 & 11.1 & $\begin{array}{l}27.5 \% \\
(15.5- \\
48.6 \%) \\
\end{array}$ & 31.1 & CPT-11 and celecoxib had some activity \\
\hline
\end{tabular}




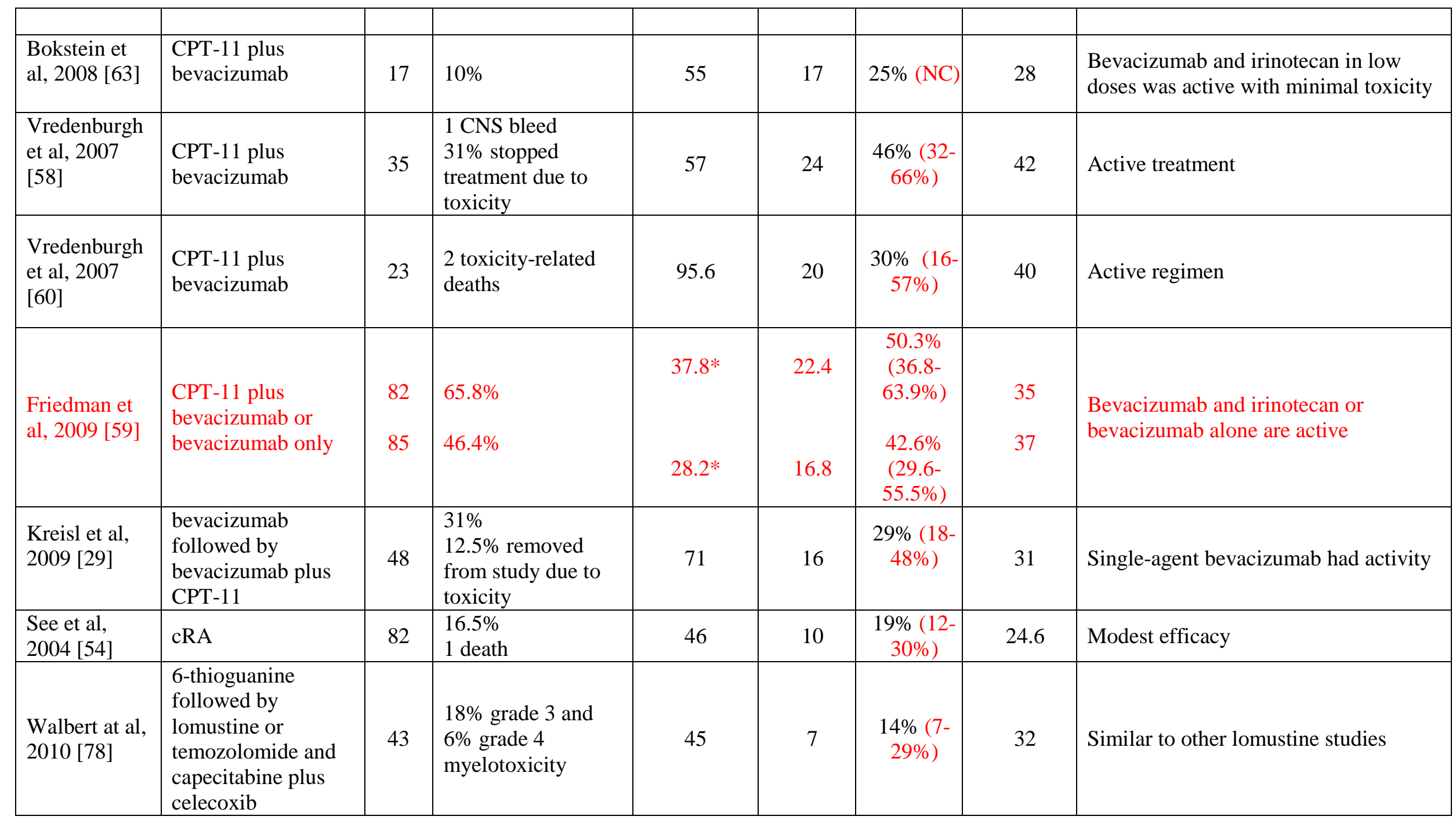

Patients had 1-7 previous chemotherapies, including temozolomide; MPFS: median progression-free survival; OS: overall survival, measured from time of relapse to death; PFS6: progression-free survival at 6 months; EIAEDs: enzyme-inducing antiepileptic drugs; EGFR: epidermal growth factor receptor; EGFR +: amplified EGFR; EGFR -: Normal EGFR; cRA: 13-cis-Retinoic acid; NC: not clear; *: Objective response. 
Table 3. Phase II clinical trials in recurrent anaplastic glioma patients after temozolomide failure

\begin{tabular}{|c|c|c|c|c|c|c|c|c|c|}
\hline Study & Treatment & No & $\begin{array}{l}\text { Toxicity levels } \\
3 / 4\end{array}$ & $\begin{array}{l}\text { Response } \\
+ \text { Stable } \\
\text { Disease, } \\
\%\end{array}$ & $\begin{array}{l}\text { MPFS, } \\
\text { weeks }\end{array}$ & $\begin{array}{l}\text { PFS6, } \\
\%\end{array}$ & $\begin{array}{l}\text { PFS12, } \\
\%\end{array}$ & $\begin{array}{l}\text { Median OS, } \\
\text { weeks }\end{array}$ & Comment \\
\hline $\begin{array}{l}\text { Desjardins et } \\
\text { al, } 2007 \text { [31] }\end{array}$ & $\begin{array}{l}\text { Imatinib } \\
\text { mesylate plus } \\
\text { hydroxyurea }\end{array}$ & 32 & $23 \%$ & 43 & 11 & 24 & 14 & 33 & $\begin{array}{l}\text { Anti-tumor activity in } \\
\text { some AG patients }\end{array}$ \\
\hline $\begin{array}{l}\text { Chamberlain } \\
\text { and Glantz, } \\
2008 \text { [86] }\end{array}$ & CPT-11 & $22(\mathrm{AO})$ & $14 \%$ & 59 & 18 & 33 & 4.5 & 22 & $\begin{array}{l}\text { Modest activity in } \\
\text { recurrent } 1 \mathrm{p} 19 \mathrm{q} \text { co- } \\
\text { deleted AO }\end{array}$ \\
\hline $\begin{array}{l}\text { Fabrini et a, } \\
2009[50]\end{array}$ & Fotemustine & 9 & $14 \%$ & & 37 & 66 & NR & $\mathrm{NC}$ & $\begin{array}{l}\text { Fotemustine was safe } \\
\text { and effective }\end{array}$ \\
\hline $\begin{array}{l}\text { Fabi et al, } \\
2009[49]\end{array}$ & Fotemustine & 26 & $35 \%$ & 54 & $\mathrm{NC}$ & $\mathrm{NC}$ & $\mathrm{NC}$ & $\mathrm{NC}$ & $\begin{array}{l}\text { Fotemustine was } \\
\text { effective especially with } \\
\text { MGMT promoter } \\
\text { methylation }\end{array}$ \\
\hline $\begin{array}{l}\text { Prados et al, } \\
2006 \text { [46] }\end{array}$ & CPT-11 & 13 & $\begin{array}{l}\text { Grade } 4 \text { (EIAED) } \\
=0\end{array}$ & ND & ND & 23.1 & ND & ND & Ineffective \\
\hline $\begin{array}{l}\text { Desjardins et } \\
\text { al, 2008 [57] }\end{array}$ & $\begin{array}{l}\text { CPT-11 plus } \\
\text { bevacizumab }\end{array}$ & 33 & $\begin{array}{l}1 \text { CNS bleed } \\
1 \text { TTP }\end{array}$ & 94 & 30 & 55 & 39 & 65 & Active regimen \\
\hline $\begin{array}{l}\text { Taillibert et } \\
\text { al, } 2009 \text { [87] }\end{array}$ & $\begin{array}{l}\text { CPT-11 plus } \\
\text { bevacizumab }\end{array}$ & $25(\mathrm{AO})$ & $\begin{array}{l}24 \% \text { intratumoral } \\
\text { bleed } \\
\text { symptomatic } \\
\text { bleed } 4 \%\end{array}$ & 88 & 20 & 42 & ND & NR & $\begin{array}{l}\text { Effective therapy for } \\
\text { recurrent AO } \\
\text { No relation to } 1 \mathrm{p} 19 \mathrm{q} \text { co- } \\
\text { deletion }\end{array}$ \\
\hline $\begin{array}{l}\text { Vredenburgh } \\
\text { et al, } 2007 \\
\text { [58] }\end{array}$ & $\begin{array}{l}\text { CPT-11 plus } \\
\text { bevacizumab }\end{array}$ & 9 & $\mathrm{NC}$ & 100 & 30 & 56 & ND & NR & $\begin{array}{l}\text { Active regimen with } \\
\text { acceptable toxicity }\end{array}$ \\
\hline $\begin{array}{l}\text { Chamberlain } \\
\text { and Johnston, } \\
2009 \text { [88] }\end{array}$ & Bevacizumab & $22(\mathrm{AO})$ & $41 \%$ & 73 & 27 & 68 & 23 & 34 & $\begin{array}{l}\text { Efficacy and acceptable } \\
\text { toxicity }\end{array}$ \\
\hline $\begin{array}{l}\text { Walbert et al, } \\
2010[78]\end{array}$ & $\begin{array}{l}\text { 6-thioguanine } \\
\text { followed by } \\
\text { lomustine or }\end{array}$ & $\begin{array}{l}23 \text { of } 31 \\
\text { on } \\
\text { lomustine }\end{array}$ & $\begin{array}{l}18 \% \text { grade } 3 \text { and } \\
6 \% \text { grade } 4 \\
\text { myelotoxicity }\end{array}$ & 68 & 24 & 44 & 44 & 54 & $\begin{array}{l}\text { Effective with acceptable } \\
\text { toxicity }\end{array}$ \\
\hline
\end{tabular}




\begin{tabular}{|l|l|l|l|l|l|l|l|l|}
\hline $\begin{array}{l}\text { temozolomide } \\
\text { and } \\
\text { capecitabine } \\
\text { plus celecoxib }\end{array}$ & & arm & & & & & & \\
\hline
\end{tabular}

Patients had 1-6 previous chemotherapies, including temozolomide; Anaplastic glioma (AG): included patients with anaplastic astrocytoma, anaplastic oligodendroglioma and anaplastic mixed glioma; AO: anaplastic oligodendroglioma; MPFS: median progression-free survival; OS: overall survival, measured from time of relapse to death; PFS6: progression-free survival at 6 months; PFS12: progression-free survival at 12 months; EIAEDs: enzyme-inducing antiepileptic drugs; TTP: thrombotic thrombocytopenic purpura; MGMT: O6-methylguanine-DNA methyltransferase; NC: not clear; ND: Not determined; NR: Not reached. 


\section{Algorithm for management of recurrent malignant glioma after}

temozolomide failure

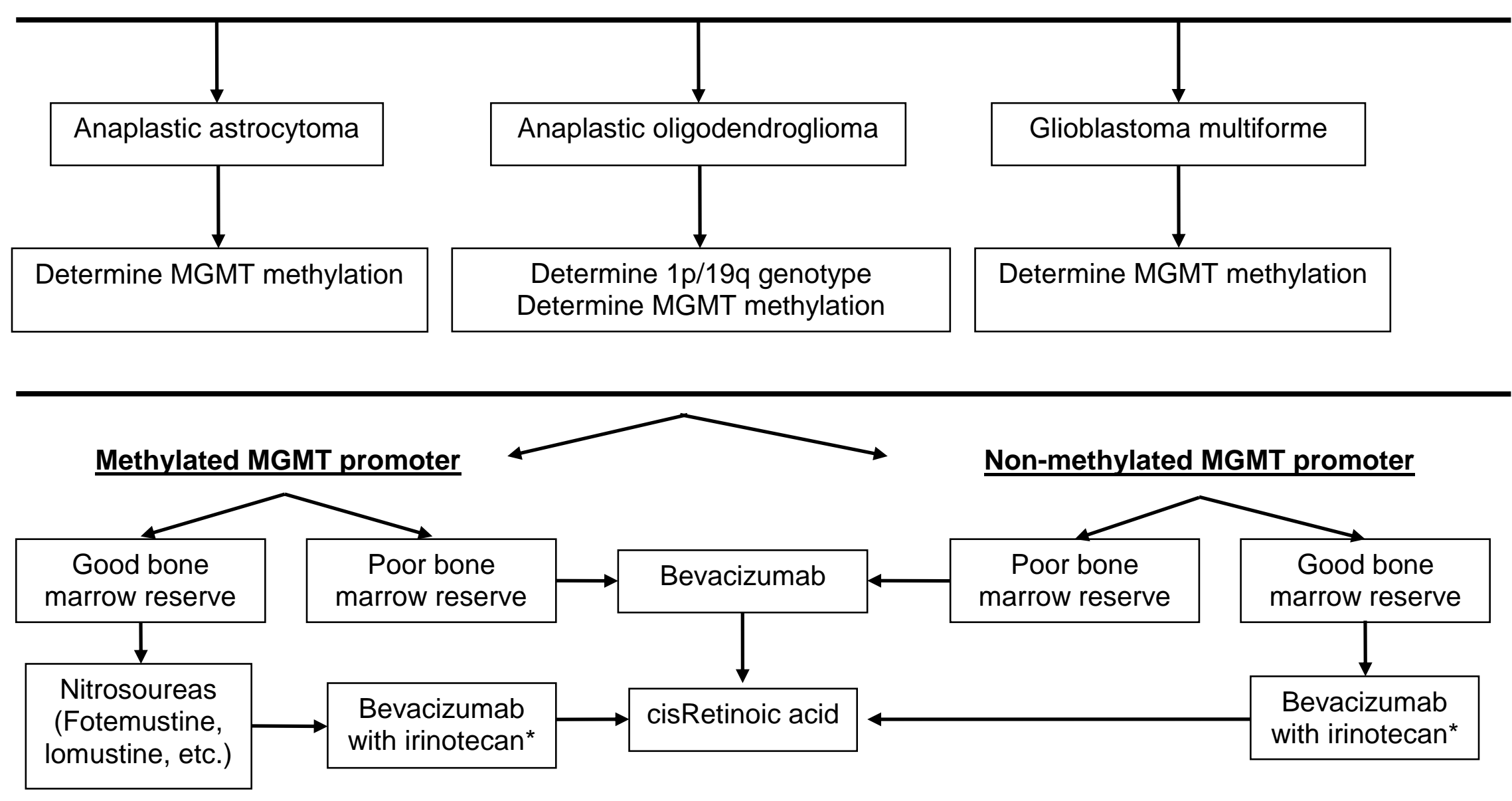

